\title{
Saltcedar recovery after herbicide-burn and mechanical clearing practices
}

\author{
KIRK C. MCDANIEL AND JOHN P. TAYLOR
}

Authors are Professor, Department of Animal and Range Sciences, Box 3-I, New Mexico State University, Las Cruces, N.M. 88003; and Wildlife Biologist, U. S. Fish and Wildlife Service, Bosque del Apache National Wildlife Refuge, P.O. Box 1246, Socorro, N.M. 87801.

\section{Abstract}

Mechanical clearing and herbicide-burn treatments were compared to evaluate saltcedar (Tamarix chinensis Lour.) control and recovery along the Rio Grande on the Bosque del Apache National Wildlife Refuge, Socorro, N.M. The herbicide-burn treatment included an aerial application of imazapyr $( \pm)-2-[4,5-$ dihydro-4-methyl-4-(1-methylethyl)-5-oxo-1H-imidazol-2-yl]-3pyridinecarboxylic acid] + glyphosate [N-(phosphonomethyl)glycine] $\left(0.6+0.6 \mathrm{~kg}\right.$ ai ha ${ }^{-1}$ rate) followed 3 years later by a prescription broadcast fire that eliminated $>99 \%$ of the standing dead stems. Six years after initial herbicide application, saltcedar mortality was $\mathbf{9 3 \%}$. Mechanical saltcedar clearing entailed removing aerial (trunks and stems) growth by blading, stacking and burning debris, followed by removal of underground plant portions (root crowns) by plowing, raking, and burning stacked material. Saltcedar mortality 3 years after mechanical clearing averaged $70 \%$, which was deemed unsatisfactory. Thus, root plowing, raking, and pile burning was repeated. Three years later, after the second mechanical clearing, saltcedar mortality was $97 \%$. Costs for the herbicide-burn treatment averaged $\$ 283 \mathrm{ha}^{-1}$, whereas mechanical control costs were $\$ 884 \mathrm{ha}^{-1}$ for the first surface and root clearing and an additional $\$ 585 \mathrm{ha}^{-1}$ for the second root clearing. Riparian managers should consider environmental conditions and restoration strategies prior to selecting a saltcedar control approach. Although control costs were significantly lower for the herbicide-burn treatment compared to mechanical clearing in this study, the choice of methods should always consider alternative control strategies for saltcedar. Frequently, combinations of methods result in more efficient, cost-effective results.

Key Words: Riparian restoration, imazapyr, glyphosate, prescribed fire, root plowing, root raking, brush control

Saltcedar (Tamarix spp.) are exotic deciduous trees that escaped from cultivation into the wild in the late 1800s (Allred 2002, Robinson 1965). Today, the trees prevail in monocultural thickets and in mixed riparian communities along most rivers in the southwestern United States (Brotherson and Field 1987,

Research was supported by New Mexico State University's Agricultural Experiment Station and funded by the U.S. Fish and Wildlife Service through the Bosque Improvement Group for a comparison of herbicide/burn and mechanical clearing saltcedar control techniques, Bosque del Apache National Wildlife Refuge, N.M.

Author to whom correspondence should be addressed: Dept. of Animal and Range Sciences, Box 3-I, New Mexico State University, Las Cruces, N.M. 88003. Phone: (505) 646-1191; Fax: 646-5441; E-mail: kmcdanie@nmsu.edu.

Manuscript accepted 26 Nov. 02.
Resumen

Se compararon tratamientos de aclareo mecánico y herbicidaquema para evaluar el control y recuperación del "Saltcedar" (Tamarix chinensis Lour.) a lo largo del río grande en el Refugio Nacional de Fauna Silvestre Bosque del Apache en Socorro, N.M. El tratamiento de herbicida-quema incluyo una aplicación aérea de imazapir ( \pm )-2-[ácido 4,5-dihidro-4-metil-4-(1-metiletil)5-oxo-1H-imidazol-2-yl]-3-piridinecarboxilico] + glifosato [N(fosfonometil)glicine] $\left(0.6+0.6 \mathrm{~kg}_{\text {ia ha }} \mathbf{h}^{-1}\right)$ seguido tres años después de quema prescrita que eliminó $>99 \%$ de los tallos muertos en pie. Seis años después de la aplicación inicial del herbicida la mortalidad del "Saltcedar" fue de $93 \%$. El aclareo mecánico del "Saltcedar" comprendió la remoción aérea del crecimiento (troncos y tallos) mediante el corte de las plantas, apilamiento y quema de los residuos seguido de la remoción de las porciones subterráneas (raíces y coronas) de las plantas mediante barbecho rastrillado y quema del material apilado. La mortalidad del "Saltcedar" 3 años después del aclareo mecánico promedio $70 \%$ el cual fue considerado insatisfactorio, Así, el barbecho, rastrillado y quema del material apilado se repitió, tres años después del segundo aclarelo mecánico la mortalidad del "Saltcedar" fue de $97 \%$. Los costos del tratamiento de herbicida-quema promedio $\$ 283 \mathrm{ha}^{-1}$ mientras que los costos del control mecánico fueron de $\$ 884 \mathrm{ha}^{-1}$ para la primer remoción del material vegetal superficial y de la limpieza de las raíces y un costo adicional de $\$ 585 \mathrm{ha}^{-1}$ para la segunda limpieza de raíces. Los manejadores de las áreas ribereñas deben considerar las condiciones ambientales y las estrategias de restauración antes de seleccionar una de ellas para el control del "Saltcedar". Aunque los costos de control fueron significativamente bajos para el tratamiento de herbicida-quema, comparados con el aclareo mecánico de este estudio, la elección de los métodos siempre debe considerar estrategias alternativas para control del "Saltcedar". Frecuentemente la combinación de métodos produce en una mayor eficiencia de resultados costo-efectividad.

Brock 1994, Frasier and Johnsen 1991). In New Mexico, saltcedar is common particularly along the Rio Grande in riparian areas formerly occupied by cottonwood (Populus spp.), willow (Salix spp.), and other native vegetation (Friedman et al. 1998). Collectively, Tamarix is composed of several genetically linked forms or ecotypes over its broad distribution range (DiTomaso and Bell 1996). With the exception of T. aphylla L. Karst. and T. parviflora DC., most species are difficult to distinguish from each other. T. chinensis Lour., T. gallica L., and T. ramosissima Ledeb. are occasionally grouped together in the literature as the same species and each has been reported as common along the 
Rio Grande (Baum 1978, DiTomaso 1998). According to Allred (2002), T. chinensis has nomenclatural priority and is the same species as $T$. ramosissima, whereas $T$. gallica does occur but is uncommon along the Rio Grande. Aside from taxonomical consideration, these species possess similar growth and ecological characteristics that make them more or less receptive to the same control practices (Everitt 1980, 1998).

During the later half of the $20^{\text {th }}$ century, numerous saltcedar control initiatives by various governmental agencies and private entities have been undertaken along the Rio Grande in New Mexico (McDaniel et al. 2000, Scurlock 1998). Reasons for controlling saltcedar include a wide range of goals, such as restoring native species in riparian communities, conserving water for irrigation and municipal use, improving stream water conveyance efficiency, protecting or enhancing habitat for endangered species, and clearing areas for agricultural and residential use. In the 1950s, saltcedar control with phenoxy herbicides including 2,4-D (2,4-dichlorophenoxy acetic acid), silvex (2,4,5-tricloropropionic acid), and 2,4,5-T (2,4,5-trichlorophenoxy acetic acid) at rates of $1.2 \mathrm{~kg}$ ai ha $\mathrm{ha}^{-1}$ or higher, was employed along the Rio Grande (Anonymous 1951, Busch et al. 1992). Guidelines for control with phenoxy herbicides were developed by several sources and foliage suppression rather than plant kill was the expectation from spraying (De Loach 1989). Recent research has focused on using imazapyr (土) - 2- [4,5-dihydro-4-methy $1-4-(1-$ methylethyl)-5-oxo-1 $\mathrm{H}$-imidazol-2-yl]-3pyridinecarboxylic acid] for saltcedar control along the Rio Grande (Taylor and McDaniel 1998a) and Pecos rivers (Duncan and McDaniel 1998) in New Mexico. Duncan and McDaniel (1998) reported about $90 \%$ saltcedar mortality after aerially applying imazapyr at a 1.2 $\mathrm{kg}$ ai ha ${ }^{-1}$ rate or as a mixture of imazapyr and glyphosate [N-(phosphonomethyl)glycine] at a $0.6+0.6 \mathrm{~kg}$ ai ha ${ }^{-1}$ rate to foliage in late summer. Following herbicide treatment, prescribed fire or chaining has been used to remove dead standing saltcedar stems prior to further riparian restoration (Taylor and McDaniel 1998b).

Root plowing has been a common mechanical method for removing saltcedar on the flood plain bordering the Rio Grande (McDaniel et al. 2000). This implement severs the root crown from the remaining root mass when the blade is dropped to a soil depth of 31 to $46 \mathrm{~cm}$ (Hollingsworth 1973). According to
Horton (1960), root plowing gave more than $90 \%$ control when this treatment was conducted during hot and dry weather, which accelerates dessication of cut stems and roots. Hollingsworth (1973); however, was skeptical of root plow treatments and reported that "the use of root plowing as a control for saltcedars all but ceased (along the Rio Grande) because soil covers stems and roots resulting in regrowth and lack of control." Taylor and McDaniel (1998a) reported that root crowns should be raked from beneath the soil surface following root plowing to increase mechanical control success. DeLoach (1989) suggested that because root plow results were inconsistent for saltcedar control, additional research was needed to achieve better results.

The Bosque del Apache National Wildlife Refuge (NWR) has included saltcedar control as part of its continuing wildlife habitat improvement program since the refuge was established in 1939 (Bosque del Apache NWR, unpublished annual narrative reports). In the late $1980 \mathrm{~s}$ renewed efforts to control saltcedar focused on rehabilitating riparian and wetland habitats in areas once naturally flooded by the Rio Grande (Taylor and McDaniel 1998b). Herbicide spraying and prescribed fire have been included as part of an ongoing effort to remove saltcedar. But the majority of rehabilitation has been accomplished, thus far, by mechanical methods using heavy equipment. This

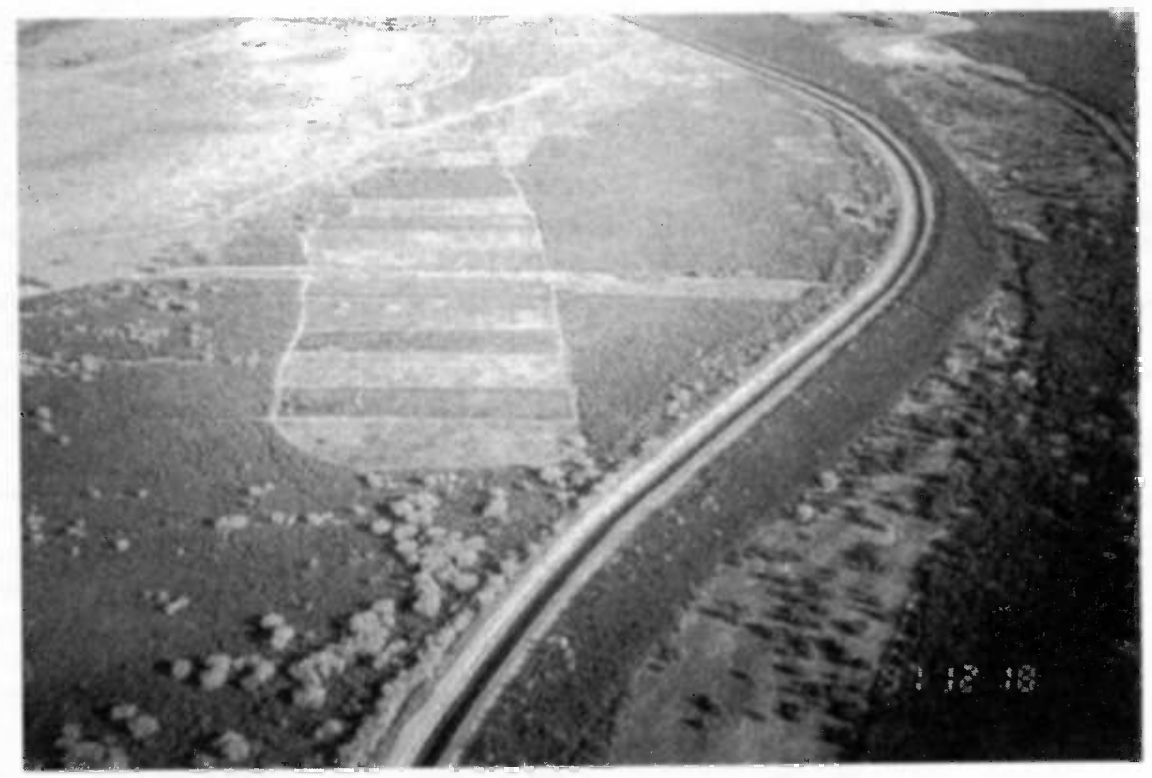

Fig. 1. Oblique aerial view of experimental plots located within a saltcedar thicket at the Bosque del Apache National Wildlife Refuge, Socorro, N.M. A low-flow conveyance channel (near center) with levees and roads serves to isolate this former portion of the flood plain from the Rio Grande (right side). Note scattered Fremont cottonwood trees in the lower left. study's objective was to compare these 2 strategies for removing saltcedar: aerial herbicide spraying and prescribed fire (herbicide-burn); and root plowing and raking control (mechanical clearing). Specifically, saltcedar regrowth after treatment and costs associated with each treatment strategy were examined.

\section{Materials and Methods}

\section{Research Area}

The experiment was conducted outside the active Rio Grande floodplain on the Bosque del Apache NWR near Socorro, New Mexico (57'47' N, 55' 24'W', 1300 $\mathrm{m})$. In the early $1940 \mathrm{~s}$, a series of wet years resulted in the most significant flooding recorded in the Middle Rio Grande Basin during the $20^{\text {th }}$ century (Whitney 1995). Partly in response to the resulting damage, the Flood Control Act of 1948 was passed, which authorized construction of an $86-\mathrm{km}$, low-flow conveyance channel adjacent to the site from San Acacia to Elephant Butte Reservoir. This structure, completed in the early 1950 s with levees and roads, was built on the western edge of the river's current channel and served to isolate the study area from the present active river flood plain (Fig. 1). Over time, the low-flow conveyance channel and other flood control structures have restricted river movement and associated natural processes that 
influence establishment and maintenance of native riparian vegetation communities (Howe and Knopf 1991, Taylor et al. 1999). In addition, several major wildfires have swept through the study area since the $1950 \mathrm{~s}$, resulting in the elimination of most fire-intolerant native trees and shrubs. Thus, when this study was initiated, the area was dominated by saltcedar as a near monocultural thicket.

The flood plain soil in the study area was formed through centuries of river cutting and deposition activities and, therefore, is a highly variable mix. In our 2- by 8-km study area (Fig. 1), soil surface textures within short distances varied from loose sands to tight silts and clays. Soil salinity, mapped by electromagnetic induction (Sheets et al. 1994), indicated the electrical conductivity of soils in the area to be mostly above $8.0 \mathrm{ds} \mathrm{m}^{-1}$. This level indicates high soil salinity, and suggests that survival and productivity of cottonwood and other native trees is likely to be poor (data not shown) (Taylor and McDaniel 1998b). Depth to water table ranged from 0.6 to $2.3 \mathrm{~m}$ and averaged 1.5 m. Except for a few remnant Fremont cottonwood (Popular fremontii S. Wats.) and black willow trees (Salix nigra Marsh) on old channel banks bordering the study area, saltcedar was the principal woody plant within experimental plots. Saltgrass (Distichlis spicata (L.) Greene) and alkali sacaton (Sporobolus airoides Torr. Torr.) grew sparsely in the understory and, we speculate, would likely be the major vegetation had saltcedar not established.

\section{Experimental Design and Saltcedar Control Treatments}

Herbicide-burn and mechanical clearing treatments were applied to 10 plots, resulting in 5 replications for each treatment in a completely randomized design. Plots measuring 82 by $305 \mathrm{~m}$ (2.5 ha) were arranged side-by-side with $10 \mathrm{~m}$ buffers (graded roads) placed between each plot.

The herbicide treatment consisted of an imazapyr plus glyphosate mixture $(0.6+$ $0.6 \mathrm{~kg}$ ai ha-1) in water with a $0.25 \% \mathrm{v} \mathrm{v}^{-1}$ nonionic surfactant, and a $0.07 \% \mathrm{v} \mathrm{v}^{-1}$ drift control agent. A Cessna T188 ${ }^{\mathrm{TM}}$ aircraft applied the herbicide on 30 August 1994, between 0700 and 0830 hours with 16 and $19^{\circ} \mathrm{C}$ air temperature, 65 and $92 \%$ relative humidity, and wind below $1 \mathrm{~m}^{\text {second }}{ }^{-1}$. The airplane speed was calibrated for 49 $\mathrm{m}$ second $^{-1}$, and the wing was fitted with a streamline boom with nozzles (D8-SS) positioned $45^{\circ}$ aft to deliver a 65 liters ha ${ }^{-1}$ total spray volume. The 5 sprayed plots remained undisturbed until early October

Table 1. Activities, time, and cost associated with saltcedar herbicide-burn and mechanical clearing treatments on the Bosque del Apache National Wildlife Refuge, N.M.

\begin{tabular}{|c|c|c|}
\hline Treatment/Activity & Hours & Cost \\
\hline & & $\left(\$ \mathrm{ha}^{-1}\right)$ \\
\hline \multicolumn{3}{|l|}{ Herbicide-burn } \\
\hline Herbicide (imazapyr \& glyphosate) & - & 202 \\
\hline Aerial application & 4 & 18 \\
\hline Prescribed burning & 12 & 63 \\
\hline Total & 16 & 283 \\
\hline \multicolumn{3}{|l|}{$\begin{array}{l}\text { Mechanical clearing } \\
1^{\text {st }} \text { Clearing }\end{array}$} \\
\hline $\begin{array}{l}\text { Aerial growth cutting, raking, } \\
\text { stacking, and pile burning }\end{array}$ & 140 & 477 \\
\hline $\begin{array}{l}\text { Root plowing, root raking, } \\
\text { stacking, and pile burning }\end{array}$ & 100 & 407 \\
\hline \multicolumn{3}{|l|}{$2^{\text {nd }}$ Clearing } \\
\hline $\begin{array}{l}\text { Root plowing, root raking, } \\
\text { stacking, and pile burning }\end{array}$ & 102 & 585 \\
\hline Total & 342 & 1,469 \\
\hline
\end{tabular}

${ }^{1}$ These cost were based on local comparable prices for equipment lease, fuel, routine maintenance, and labor.

1997, when prescribed broadcast burns were conducted to remove dead standing saltcedar stems. Each herbicide plot was burned separately with fires ignited using a truck-mounted terra-torch ${ }^{1}$. Conditions during prescribed burning included 28 to $32^{\circ} \mathrm{C}$ air temperature, 31 to $42 \%$ relative humidity, and wind speeds of 1 to $3 \mathrm{~m}$ second $^{-1}$. In 20 to 30 minutes, fire removed nearly all the standing dead and desiccated saltcedar stems within a plot. An exception was in 1 sprayed plot where about $15 \%$ of the woody material did not burn, because saltcedar skeletons were scattered too widely to carry the fire.

Mechanical clearing involved a 2-stage approach, in which saltcedar aerial trunk and stem growth was removed first and then root material was extracted from the soil. In June 1995, saltcedar aerial growth was cleared in the 5 experimental plots using two, D-7 class bulldozers. Fitted with front-mounted blades, the bulldozers pushed over the standing stems and cut them near the soil surface. A $1.9-\mathrm{m}^{-3}$ capacity, articulating loader adapted with a brush rake worked behind the bulldozers to gather and stack the cut debris into piles. These piles were allowed to dry for about a month before being doused with diesel fuel and ignited. Clearing aerial growth required 140 hours and took about a month to complete (Table 1). In September 1995, root plowing was accomplished using 1 of the D-7 bulldozers equipped with a $6 \mathrm{~m}$ wide blade that severed the roots about $40 \mathrm{~cm}$ below the sur-

${ }^{\mathrm{T}}$ Firecon, Inc., P.O. Box 657, Ontario, Ore. 97914 face. The second D-7 bulldozer was fitted with a hydraulic, 6.4-m wide root rake containing teeth $1.2 \mathrm{~m}$ in length and spaced $38 \mathrm{~cm}$ apart to rake root material into windrows. The articulating loader later consolidated windrowed material into piles that subsequently were burned. Three years after the initial clearing operation, saltcedar regrowth was common in the 5 mechanically cleared experimental plots, thus a second clearing operation was necessary. In June 1998, all mechanical plots were retreated using the root plowing, root raking, gathering and pile burning sequence. This operation required about 102 hours to complete (Table 1 ).

\section{Vegetation Sampling}

Prior to treatment in August 1994, 4 parallel permanent belt transects were spaced evenly $50 \mathrm{~m}$ apart in each experimental plot. Transects, $4 \mathrm{~m}$ wide and $50 \mathrm{~m}$ long, were used to determine saltcedar density (plant units $\mathrm{ha}^{-1}$ ), and a $50 \mathrm{~m}$ tape was placed at the belt transect's center to determine canopy cover intercept (percent cover) (Burnham et al. 1980). Saltcedar was multistemmed, thus a plant unit was defined as a single plant with stems originating from a common root crown near or just below the soil surface. Live stems converging near the base of each plant unit were counted separately and were recorded as live basal stems per plant unit. Pretreatment density and percent cover estimates of live saltcedar were later compared with similar measurements taken after treatment in autumn 1995, 1996, 1997, 1998, 1999, and 2000. Percent saltcedar control was determined yearly by 
comparing live saltcedar density in experimental plots with the pretreatment densities. Partially defoliated or damaged plants were considered alive. At both ends of a transect ( 0 and $50 \mathrm{~m}$ point), a modification of the point-center quarter technique (Bonham 1989) was used to measure distance to the nearest live saltcedar plant in each of 4 quarters to determine plant spacing $(\mathrm{m})$. To avoid overlapping other transects, only plants within $25 \mathrm{~m}$ of the center point were recorded. Height $(\mathrm{m})$, width $(\mathrm{m})$, and the number of live basal stems per plant unit were measured on each of the nearest saltcedar plants. Canopy volume $\left(\mathrm{m}^{3}\right)$ was computed by multiplying height and diameter measurements. Data collected were distributed normally and error variances were homogeneous for all variables analyzed, including plant density, cover, plant spacing, height, volume, and live basal stems per plant unit. A repeated measures analysis of variance, with treatment as the main plot factor and survey year as the repeated measures factor, was used to analyze data using SAS (1985) procedures. If F-tests detected significant treatment differences $(\mathrm{P}>0.05)$ then Fisher's LSD ( $\alpha=0.05)$ was used as a mean separation technique.

\section{Results}

\section{Pretreatment Conditions}

According to records kept by the Bosque del Apache NWR, at least 3 wildfires passed through the study area since the 1940s. The most recent wildfire in spring 1986 killed most aerial saltcedar

Table 2. Pretreatment saltcedar measurements averaged from 10 experimental plots 2.5 ha in size on the Bosque del Apache National Wildlife Refuge near Socorro, N.M. in October 1994.

\begin{tabular}{lcc}
\hline \hline Measurement & Mean & Standard \\
Error
\end{tabular}

vegetation and many charred stems were still standing when pretreatment measurements were taken in August 1994. Because fire does not kill saltcedar roots, there was prolific sprouting from buds on the buried root crown. This resulted in saltcedar regrowth of relatively uniform stature and height, similar to that of the residual charred stems. Pretreatment measurements indicated no significant difference among the experimental plots in plant density, cover, spacing, height, volume, or live basal stems per plant unit (Table 2). Saltcedar density averaged 7,112 plant units $\mathrm{ha}^{-1}$, and live stems originating near the plants base ranged from as few as 4 to as many as 130 stems per plant unit. Canopy cover determined by line intercept ranged from 34 to $90 \%$ and averaged $56 \%$ while plant spacing ranged from 0.1 to $9.3 \mathrm{~m}$ and averaged $1.3 \mathrm{~m}$. Plant height ranged from 0.6 to $6.0 \mathrm{~m}$ and averaged $2.3 \mathrm{~m}$, whereas plant volume ranged from 0.01 to $13 \mathrm{~m}^{3}$ and averaged $0.9 \mathrm{~m}^{3}$.

\section{Treatment Comparisons}

Treatment-by-year interactions occurred for all variables, including plant density, cover, spacing, height, volume, and live basal stems per plant unit. The interactions were expected because the initial mechanical clearing effort provided inconsistent saltcedar control by plot and resulted in variable data the first 3 years after treatment. The second mechanical clearing provided high and consistent saltcedar control across experimental plots. Thus, after this operation, there were no differences in measured variables for the next 3 years. In contrast, the herbicide treatment gave consistent saltcedar control results across all experimental plots every year.

Live plant densities were lower in herbicide-burn plots compared with mechanically cleared plots in 1995, 1996, and 1997, but herbicide-burn plots had higher plant densities in 1998 and 2000 (Table 3). Treatments did not differ in 1999. Few plants possessed foliage in herbicide-treated plots the first 3 years after treatment. In 1998, the first year after prescribed fires, saltcedar regrowth from burned stumps and buried root crowns was easily noticed, and plant density increased compared to previous years. Saltcedar density contin-

Table 3. Mean saltcedar plant density (plants ha ${ }^{-1}$ ), canopy cover $(\%)$, spacing $(\mathrm{m})$, height $(\mathrm{m})$, volume $\left(\mathrm{m}^{3}\right)$, and live basal stems per plant unit $(\mathrm{no}$. plant unit $^{-1}$ ) in herbicide-burn and mechanical clearing treatments in 1995 through 2000 on the Bosque del Apache National Wildlife Refuge, N.M.

\begin{tabular}{|c|c|c|c|c|c|c|}
\hline Treatment/Year & Density & Canopy Cover & Spacing & Height & Volume & Basal Stems \\
\hline & $\left(\right.$ plants ha ${ }^{-1}$ ) & $(\%)$ & (m) & (m) & $\left(\mathrm{m}^{-3}\right)$ & (no. plant unit ${ }^{-1}$ ) \\
\hline \multicolumn{7}{|l|}{ Herbicide-burn } \\
\hline 1995 & $6 \mathrm{a}^{1} \mathrm{~A}^{2}$ & $0.0 \mathrm{aA}$ & $0.0 \mathrm{aA}$ & $0.0 \mathrm{aA}$ & $0.0 \mathrm{aA}$ & $0.0 \mathrm{aA}$ \\
\hline 1996 & $83 \mathrm{aA}$ & $0.8 \mathrm{aA}$ & $0.0 \mathrm{aA}$ & $0.0 \mathrm{aA}$ & $0.0 \mathrm{aA}$ & $0.0 \mathrm{aA}$ \\
\hline 1997 & $137 \mathrm{aA}$ & $1.3 \mathrm{aA}$ & $0.0 \mathrm{aA}$ & $0.0 \mathrm{aA}$ & $0.0 \mathrm{aA}$ & $0.0 \mathrm{aA}$ \\
\hline 1998 & $287 \mathrm{bB}$ & $2.9 \mathrm{bB}$ & $4.2 \mathrm{aB}$ & $1.4 \mathrm{bB}$ & $0.6 \mathrm{aB}$ & $8.3 \mathrm{aB}$ \\
\hline 1999 & $452 \mathrm{aC}$ & $6.3 \mathrm{aC}$ & $5.3 \mathrm{aC}$ & $2.0 \mathrm{aC}$ & $1.9 \mathrm{aC}$ & $7.0 \mathrm{aB}$ \\
\hline 2000 & $522 \mathrm{bC}$ & $11.5 \mathrm{bD}$ & $5.2 \mathrm{aC}$ & $2.7 \mathrm{aD}$ & $3.2 \mathrm{aD}$ & $12.3 \mathrm{aC}$ \\
\hline \multicolumn{7}{|c|}{ Mechanical clearing } \\
\hline 1995 & $937 \mathrm{bA}$ & $5.0 \mathrm{aAB}$ & $6.8 \mathrm{bB}$ & $0.4 \mathrm{bA}$ & $0.1 \mathrm{bA}$ & $1.6 \mathrm{aA}$ \\
\hline 199 & $2287 \mathrm{bB}$ & $13.0 \mathrm{bBC}$ & $3.2 \mathrm{bA}$ & $1.5 \mathrm{bB}$ & $0.5 \mathrm{bB}$ & $6.3 \mathrm{bBC}$ \\
\hline 1997 & $2142 \mathrm{bB}$ & $17.0 \mathrm{bC}$ & $2.7 \mathrm{bA}$ & $1.9 \mathrm{bC}$ & $1.5 \mathrm{bB}$ & $7.8 \mathrm{bB}$ \\
\hline 1998 & $52 \mathrm{aA}$ & $0.4 \mathrm{aA}$ & $5.2 \mathrm{aAB}$ & $0.5 \mathrm{aA}$ & $0.1 \mathrm{bA}$ & $4.9 \mathrm{bC}$ \\
\hline 1999 & $200 \mathrm{aA}$ & 4.0aAB & $10.6 \mathrm{bC}$ & $2.3 \mathrm{aD}$ & $2.0 \mathrm{aB}$ & $8.1 \mathrm{aB}$ \\
\hline 2000 & $180 \mathrm{aA}$ & $4.7 \mathrm{aAB}$ & $10.7 \mathrm{bC}$ & $2.7 \mathrm{aE}$ & $3.1 \mathrm{aC}$ & $12.5 \mathrm{aD}$ \\
\hline
\end{tabular}

Treatment means by year followed by the same lower case letter are not different $(\mathrm{P}>0.05)$.

${ }^{2}$ Year means within a treatment followed by the same upper case letter are not different $(\mathrm{P}>0.05)$. 
ued to increase in herbicide-burn plots in 1999 and 2000 compared to previous years, but these were not different from each other. On mechanically cleared plots, plant density was lower in 1995, 1998, 1999, and 2000, than in 1996 and 1997. Higher densities in 1996 and 1997 reflected poor control achieved after the initial clearing effort.

Percent cover was less than $1 \%$ on mechanically cleared and herbicide-burn plots in 1995, but saltcedar cover was higher in mechanically cleared plots in 1996 and 1997 (Table 3). Saltcedar cover was higher in herbicide-burn plots than in mechanical plots after the second clearing in 1998 and 2000, but no differences were found in 1999. The prescribed fires apparently stimulated saltcedar sprouting resulting in an increased percent cover each year after burning relative to pre-burn years. Saltcedar cover increased rapidly on mechanically cleared plots from 1995 to 1997. After re-clearing in 1998 , percent cover did not increase in 1999 or 2000.

Saltcedar were more widely spaced in herbicide-burn than mechanically cleared plots in 1995, 1996, and 1997 (Table 3). Following burning and reclearing activities, spacing was similar between treatments in 1998. But in 1999 and 2000, plant spacing was greater on mechanically cleared plots. Within herbicide-burn plots, plant spacing was greater prior to burning compared with that recorded afterwards. Plant spacing in mechanical plots was similar to 1995 and 1998, immediately after clearing activities. However, spacing was much greater in 1999 and 2000 than 1996 and 1997, reflecting more successful control following the second clearing effort.

Plant height and volume were less in herbicide-burn plots compared with mechanically cleared plots in 1995, 1996, and 1997. But in 1998, herbicide-burn plots recorded greater height and volume (Table 3). In 1999 and 2000, plant height and volume were nearly the same among treatments. Saltcedar height and volume on mechanically cleared plots were lowest and not different in 1995 and 1998, following clearing activity; growth was rapid in subsequent years following these events.

The number of live basal stems per plant unit was similar on herbicide-burn and mechanically cleared plots in 1995 , but not in 1996 or 1997 when more stems were found on saltcedar growing within mechanically cleared plots (Table 3 ). Stems increased on saltcedar following burning in 1998, but there were no treat- ment differences in the number of live basal stems per plant unit in 1999 or 2000 Live basal stem numbers were lowest in 1995, following the first mechanical clearing activity. They increased after the second clearing in 1998, and were highest in 2000.

\section{Discussion}

\section{Saltcedar Control in the Herbicide- Burn Treatment}

Chemically treated saltcedar needles discolored 2 to 3 weeks after the mixture of imazapyr plus glyphosate was applied in late August 1994. But foliage did not shed until mid-November; about the same time that saltcedar normally defoliates and enters winter dormancy in this area. On the Bosque del Apache NWR, saltcedar usually initiates new stem and needle growth in early April but none of the sprayed plants had any green foliage when the site was visited in May 1995. During the first post treatment survey in October 1995 , a total of 2,840 plants were observed from transects in the sprayed plots, but only 2 had any green growth. These plants possessed the highly restricted, gnarled primordial growth from axillary buds on lower stems that typifies imazapyr damage (Duncan and McDaniel 1998). More live saltcedar plants were counted in October 1996 (39 total live, 99\% control) and October 1997 (66 total live, $98 \%$ control). But again, these plants had mainly gnarled primordial growth. It was noticed that surviving plants usually occurred in a streaked pattern, suggesting a reduced amount of herbicide may have been intercepted by the canopy because the spray swath did not provide complete overlap coverage.

After data collection in October 1997, prescribed burns were conducted separately within each sprayed plot, and the heat created eliminated nearly all $(>99 \%)$ of the dead standing saltcedar stems. Prescribed burning was conducted safely, despite the close proximity of adjacent expanses of untreated monocultural saltcedar. Burn prescription conditions required moderate air temperature, high relative humidity, and light wind, resulting in relatively high moisture content of adjacent live saltcedar fuels. Under such conditions, fuel ignition was difficult if not impossible in these adjacent stands. One year after burning, during the 1998 evaluation, we noticed that the stems of dead saltcedar always burned completely to the ground, whereas most sprouting plants still had 1 or 2 standing charred stems. This indicated that these stems were probably alive before the fire and were too succulent to burn completely. Sprouting was evident from either the lower portions of these stems or from the root crown. By comparing plant density prior to treatment in the herbicide-burn plots to that recorded in October 2000, saltcedar control was estimated to be $93 \%$. Herbicide cost $\$ 202$ $\mathrm{ha}^{-1}$ and aerial application and other minor labor costs were $\$ 18 \mathrm{ha}^{-1}$. Prescribed burning costs were about $\$ 63 \mathrm{ha}^{-1}$ and combined, the total treatment cost was about $\$ 283 \mathrm{ha}^{-1}$ (Table 1).

\section{Saltcedar Control in the Mechanical \\ Clearing Treatment}

Nearly 140 hours, over a 4-week period from late June to mid-July 1995, were required to surface cut, rake, stack, and burn saltcedar aerial growth in the 5 plots randomly assigned for mechanical clearing. Because of overheating problems, heavy equipment usually was only operated for 3 to 4 hours in the early morning. Root plowing, raking, stacking, and pile burning required 100 hours to complete and was delayed by the onset of summer rains in July and August. This work started in early September after the rains ended and continued through November 1995. Surface aerial clearing costs totaled about $\$ 477 \mathrm{ha}^{-1}$, and costs related to root material removal totaled about $\$ 407 \mathrm{~h}^{-1}$. These expenses were based on comparable local equipment lease, fuel, routine maintenance, and labor costs. Three years after the initial mechanical clearing effort, saltcedar control among experimental plots ranged from 54 to $88 \%$ and averaged $70 \%$, which was deemed unacceptable. The second saltcedar clearing effort was performed in June and July 1998 under hotter and drier conditions, and few live saltcedar remained after this operation. Saltcedar removal costs during the second effort were about $\$ 585 \mathrm{ha}^{-1}$. Machine hours were increased during this operation by the presence of a weedy annual plant community primarily composed of kochia (Kochia scoparia L. Roth ex Schrad.) and Russian thistle (Salsola kali L.), which hindered root removal. Combined costs for the 2 mechanical clearing treatments totaled $\$ 1,469 \mathrm{ha}^{-1}$ (Table 1).

Poor saltcedar control following the first mechanical clearing effort was reflected through greater plant density and cover than sprayed plots during the first 3 years after treatment (Table 3). Plant height, volume, and live basal stems per plant unit also were greater in mechanically cleared 
plots. Timing of the initial clearing operation largely contributed to poor mechanical control. Aerial growth was not cleared until mid-July which delayed root plowing and raking until after the summer rainy season. By the time root work began in early September, cooler weather and moister substrates prevailed. Clearing aerial growth should have been accomplished during cooler winter weather to avoid overheating equipment and to allow for longer operating periods. Ideally, root plowing and raking should have been completed prior to the summer rainy season, as was conducted during the second clearing operation in this study.

\section{Management Implications}

Removing saltcedar is a necessary first step towards restoring riparian habitats along many Southwestern river systems (Taylor 1999). Areas that become saltcedar thickets are likely to remain as such indefinitely unless interventive steps are taken to remove plants. In our study area, as an example, saltcedar established in the 1940s following significant flooding events. Periodic wild fires through the area enabled saltcedar to thrive at the expense of fire-intolerant native trees and shrubs (Busch 1995). When this study began in 1994, there were virtually no other plant species present except saltcedar and, by all indications, the plant community would remain this way into the foreseeable future.

When selecting a control strategy for saltcedar, it is important to consider factors related to the plant and its environment, such as the plant's age, growth characteristics and associated vegetation. Areas with dense, even-aged saltcedar and little associated vegetation are better suited for the herbicide-burn treatment than areas that have mixed riparian vegetation. Imazapyr and glyphosate are nonselective herbicides and potentially can kill other desirable plants. Thus, this treatment in combination with prescribed fire should not be used where protection of native species is required (Duncan and McDaniel 1998). Similarly, mechanical clearing can be nonselective and shares many of the same environmental drawbacks as an herbicide-burn treatment when desirable plant protection is needed.

Applied by itself, imazapyr is more effective than glyphosate for saltcedar control (Duncan and McDaniel 1997). Imazapyr's activity is enhanced when above and below-ground plant parts are proportional because the chemical is readily moved in both xylem and phloem after root or foliar absorption. Imazapyr is rapidly absorbed into the foliage (within 24 hour) with plant death resulting primarily from acetolactate synthase inhibition. Secondary effects include disruption of photosynthate translocation, hormone and enzyme activity, and interference in DNA synthesis and cell growth (Weed Science Society of America 2002). According to Sprenger et al. (2002), spraying saltcedar regrowth within 1 or 2 years following surface removal of trunks and shoots (i.e. by burning or mechanical removal) should be discouraged, presumably because of the imbalance created in source/sink relationships.

When conducting mechanical clearing treatments, root crown removal is critical for assuring control (Horton 1960). Operators must be cognizant of root plowing depths to ensure that root crowns are indeed severed from the remaining root mass and then pulled from the soil using raking implements. The root mass is smaller and the crown is closer to the surface on younger plants than on older, more mature vegetation, thus, determination of the optimal depth for root plowing must be adjusted accordingly.

Frequently, wet conditions or high water tables in floodplain habitats preclude using heavy equipment or render their use for removing root material ineffective due to excessive soil moisture. The herbicideburn treatment for saltcedar control would, therefore, be attractive to managers in areas where equipment access is not possible. Imazapyr currently is registered for noncropland areas and for riparian and wildlife restoration in New Mexico, whereas glyphosate is registered for noncropland and aquatic habitats. Imazapyr may be used in low-lying areas after water has receded. Imazapyr and glyphosate degrade rapidly through microbial breakdown and photolysis, and movement is limited in the soil even when treated sites are inundated by water (Sisneros 1991, Taylor 1999). Imazapyr has soil residual activity (Sisneros 1991), but no ill effects on germinating seedlings or planted materials were reported after saltcedar was aerially sprayed during other studies on the Bosque del Apache NWR (Taylor and McDaniel 1998a, Sprenger et al. 2002).

Once saltcedar is removed, follow-up restoration work can be markedly different depending on water availability for flooding or irrigation. On the Bosque del Apache NWR, a network of canals and irrigation ditches throughout the refuge allows water from the Rio Grande to be used to mimic flooding and promote native seed germination to naturally vegetate sites (Stromberg 1997, Rood et al.
1998, Taylor et al. 1999). Native trees and shrubs should be planted on sites without flooding potential (Swenson and Mullins 1985, Anderson and Ohmart 1982, Anderson and Laymon 1989, Taylor and McDaniel 1998b). Herbaceous weeds often are serious competitors to planted vegetation (Anderson and Laymon 1989). Therefore ground disturbance, such as that incurred through clearing saltcedar vegetation mechanically, could be avoided using the herbicide-burn control approach.

Where flooding is used to promote natural riparian vegetation regeneration, soil disturbance and/or sediment depostion is required (Segelquist et al. 1993, Stromberg 1997, Rood et al. 1998, Sprenger et al. 2002). Saltcedar clearing by mechanical practices provides this disturbance and opens areas to sunlight needed for seedling growth and survival (Taylor et al. 1999). The herbicide-burn treatment also opens saltcedar canopies and, when flooded with sediment-laden flows, enhances the establishment and survival of replacement native riparian plants with minimal soil disturbance.

Cost and time greatly influence strategic choices related to saltcedar control and riparian restoration. In this study, for an additional $7 \%$ control achieved using the 2 mechanical clearing treatments, costs were $520 \%$ higher than the herbicide-burn treatment. The herbicide application was made in a single morning and burning accomplished in 1 day. By comparison, the initial mechanical clearing operation was conducted over a 6-month period (June to November), and the second operation was completed over a 2-month period (June to July). To reduce costs where thorough control is needed or soil disturbance is required as part of a restoration strategy, treatment combinations should be considered. As an example, saltcedar aerial growth can be removed using the herbicide-burn treatment for less than half the cost of mechanical surface aerial clearing. This method also reduces wear and tear on heavy equipment. If resulting resprout densities are unacceptable and/or if soil disturbance is needed for subsequent restoration, follow-up root plowing and raking can be used, which still provides a savings compared to using only the mechanical clearing treatment.

\section{Literature Cited}

Allred, K. W. 2002. Identification and taxonomy of Tamarisk (Tamaricaceae) in New Mexico. Desert Plants. 
Anderson, B. W. and S. A. Laymon. 1989. Creating habitat for the yellow-billed cuckoo (Coccyzus americana), p. 1-15. In: D. Abell (ed.) Calif. Riparian System Conf. University California-Davis Gen. Tech. Rep. PFW110:468-472.

Anderson, B. W and R. D. Ohmart. 1982. Revegetation and wildlife enhancement along the lower Colorado River. USDI Bur. of Reclamation. Cont. No. 7-07-30-V0009. $215 \mathrm{pp}$.

Anonymous. 1951. Report to the saltcedar interagency council task force for $\mathrm{New}$ Mexico. Albuquerque, N.M. 136 pp.

Baum, B. R. 1978. The genus Tamarix. Jerusalem: Israel Acad. of Sci. and Humanities. 209 p.

Bonham, C. D. 1989. Measurements for terrestrial vegetation. J. Wiley \& Sons. New York, N.Y. 338p.

Brock, J. H. 1994. Tamarix spp. (Saltcedar) an invasive exotic woody plant in arid and semiarid riparian habitats of western USA, p. 27-44. In: L. C. De Waal (ed.) Ecology and Management of Invasive Riverside Plants. J. Wiley \& Sons. New York, N.Y.

Brotherson, J. D. and D. Field. 1987. Tamarix: impacts of a successful weed. Rangelands 9:110-112.

Brotherson, J. D. and V. Winkel. 1986. Habitat relationships of saltcedar (Tamarix ramosissima) in central Utah. Great Basin Nat. 46:535-541.

Burnham, K. P., D. R. Anderson, and J. L. Laake. 1980. Estimation of density from line transect sampling of biological populations. Wildl. Monogr. 72.

Busch, D. E. 1995. Effects of fire on southwestern riparian plant community structure. Southwest Nat. 40:259-267.

Busch, D. E., L. Herbranson, J. E. Pinkney, and D. Sisneros. 1992. Vegetation management study: lower Colorado river. Phase I report. USDI Bur. of Reclamation Lower Colorado Region, Boulder City, Nev. 103 pp.

DeLoach, J. C. 1989. Saltcedar, a weed of western North American riparian areas: A review of its taxonomy, biology, harmful and beneficial values, and its potential for biological control. Final Rep. for USDI Bur. of Reclamation, Lower Colorado Region, Boulder City, Nev. 296 p.

DiTomaso, J. M. 1998. Impact, biology, and ecology of saltcedar (Tamarix spp.) in the southwestern United States. Weed Technol. 12:326-336.

DiTomaso, J. M. and C. E. Bell (eds.). 1996. Proceedings of the Saltcedar Management Workshop June 12, 1996. Rancho Mirage, Calif. Univ. of California-Davis Coop. Ext Serv. $61 \mathrm{p}$.

Duncan, K. W. and K. C. McDaniel. 1998. Saltcedar (Tamarix spp.) management with imazapyr. Weed Technol. 12:337-344.

Everitt, B. L. 1980. Ecology of saltcedar - a plea for research. Environ. Geol. 3:77-84.

Everitt, B. L. 1998. Chronology of the spread of Tamarisk in the central Rio Grande. Wetlands 18:658-668.
Frasier, G. W. and T. N. Johnsen, Jr. 1991. Saltcedar (Tamarisk): classification, distribution, ecology, and control, p. 377-386. In: L. F. James, J. O. Evans, M. H. Ralphs, and R. D. Childs (eds.) Noxious Range Weeds. Westview Press. Boulder, Colo.

Friedman, J. M., W. R. Osterkamp, M. L. Scott, and G. T. Auble. 1998. Downstream effects of dams on channel geometry and bottomland vegetation: regional patterns in the Great Plains. Wetlands 18:619-633.

Horton, J. S. 1960. Use of a root plow for clearing Tamarisk stands. USDA For. Serv. Rocky Mtn. For. and Range Exp. Sta. Res. Note $50.5 \mathrm{pp}$.

Hollingsworth, E. B. 1973. Summary report on phreatophyte research, Los Lunas, New Mexico 1961-1972. Los Lunas, N.M.: USDA Unnumbered Document. $18 \mathrm{p}$.

Howe, W. H. and F. L. Knopf. 1991. On the imminent decline of Rio Grande cottonwoods and central New Mexico. The Southwest. Nat. 36:218-224.

McDaniel, K. C., K. W. Duncan, and J. P. Taylor. 2000. Saltcedar (Tamarix spp.) control in New Mexico, p. 173-183. In: Proceedings, rangeland weed and brush management: the next millennium symposium and workshop. Texas A\&M Res. and Exten. Center, San Angelo, Tex.

Robinson, T. W. 1965. Introduction, spread, and area extent of saltcedar (Tamarix) in the western states. USGS Prof. Paper 491-A.

Rood, S. B., A. R. Kalischuk, and J. M. Mahoney. 1998. Initial cottonwood seedling recruitment following the flood of the century of the Oldman river, Alberta, Canada. Wetlands 18:557-570.

SAS Institute Inc. 1985. SAS user's guide: Statistics, version 5 edition. SAS Institute Inc. Cary, N.C.

Scurlock, D. 1998. From the Rio to the Sierra: an environmental history of the middle Rio Grande basin. USDA For. Serv. Gen. Tech. Rep. RMRS-GTR-5. Albuquerque, N.M. 440 pp.

Segelquist, C. A., M. L. Scott, and G. T. Auble. 1993. Establishment of Populus deltoids under simulated alluvial groundwater declines. Amer. Midland Nat. 130:274-285.

Sheets, K. R., J. P. Taylor, and J. M. H. Hendricks. 1994. Rapid salinity mapping by electromagnetic induction for determining riparian restoration potential. Restoration Ecol. 2:242-246.

Sisneros, D. 1991. Herbicide analysis: lower Colorado River saltcedar vegetation management study. USDI Bur. of Reclamation. Gen. Tech. Rep. R-91-06.

Sprenger, M. D., L. M. Smith, and J. P. Taylor. 2002. Restoration of riparian habitats using experimental flooding. Wetlands 22:49-57.

Stromberg, J. C. 1997. Growth and survivorship of Fremont cottonwood, Goodding willow, and saltcedar seedlings after large floods in central Arizona. Southwest. Nat. 57:198-208.
Swenson, E.A. and C.L. Mullins. 1985. Revegetating riparian trees in southwestern floodplains. p. 135-138. In: R.R. Johnson, C.D. Ziebell, D.R. Patton, P.F. Ffolliott, and R.H. Hamre (eds) Riparian Ecosystems and Their Management: Reconciling Conflicting Uses. U.S. Forest Serv. Gen. Tech. Rep. RM120

Taylor, J. P. 1999. Conversion of saltcedar monocultures and mixed saltcedar/native bosque to native bosque, wetland, and agricultural habitats. Environ. Assess. USDI Fish and Wildl. Serv. Albuquerque, N.M. 62 pp.

Taylor, J. P. and K. C. McDaniel. 1998a. Restoration of saltcedar (Tamarisk spp.)infested floodplains on the Bosque del Apache National Wildlife Refuge. Weed Technol. 12:345-352.

Taylor, J. P. and K. C. McDaniel. 1998 b. Riparian management on the Bosque del Apache National Wildlife Refuge. N.M. J. of Sci.. 38:219-232.

Taylor, J. P., D. B. Wester, and L. M. Smith. 1999. Soil disturbance, flood management, and riparian woody plant establishment in the Rio Grande floodplain. Wetlands 19:372-382.

Weed Science Society of America. 2002. Herbicide handbook. Eighth edition. Weed Sci. Soc. of Amer., Lawrence, Kans. 493 p.

Whitney, J. C. 1995. The Middle Rio Grande: its ecology and management. pp. 4-21. In: D. W. Shaw and D. M. Finch (eds.). Desired future conditions for southwestern riparian ecosystems: bringing interests and concerns together. USDA For. Serv. Gen. Tech. Rep. RM-GTR-272. Fort Collins, Colo. 